\title{
AJANKOHTAISTA
}

\section{Aatoksissa iäkkäiden päivittäisen toimintakyvyn ja sosiaalisen osallistumisen edistäminen Sävelsirkku-ryhmätoiminnoilla}

Aktivoivan, strukturoidun ryhmätoiminnan vaikutus iäkkäiden päivittäiseen toimintakykyyn ja sosiaaliseen osallistumiseen palvelukodissa (AATOS) -tutkimushanke käynnistyi syksyllä 2020 kahden yliopiston, yhden ammattikorkeakoulun sekä yhden yksityisen palveluntuottajan ja yhden koulutus- ja konsultaatioorganisaation yhteistyönä. Hankkeen oletettu kesto on vuoden 2023 loppuun. Tarkoituksena on kuvata ja arvioida hoitajan ohjaaman ryhmätoiminnan vaikutuksia tehostetun palveluasumisen asiakkaiden käytösoireisiin, päivittäisistä toiminnoista selviytymiseen ja sosiaaliseen osallistumishalukkuuteen. Hankkeen lyhennetyllä AATOS-nimellä halutaan korostaa sitä, että keskiössä ovat iäkkäät ihmiset ja viitata aktivoivan, strukturoidun ryhmätoiminnan vaikutuksiin iäkkäiden päivittäiseen toimintakykyyn ja sosiaaliseen osallistumiseen hoivakodissa. Interventiotutkimushankkeen toimintaympäristönä ovat yksityisen palveluntuottajan hoivakodit $(n=15)$ eri puolella Suomea.

\section{Hankkeen tausta}

Iäkkäiden henkilöiden ympärivuorokautisen hoidon painopiste on Suomessa siirtynyt laitoshoidosta tehostettuun palveluasumiseen. Pitkäaikaista ympärivuorokautista hoitoa tuotetaan ensisijaisesti asumispalveluiksi luettavissa tehostetun palveluasumisen toimintayksiköissä. Tehostetussa palveluasumisessa oli asiakkaita vuoden 2020 lopussa 46262, joista vajaa puolet asui kunnallisen palvelutuotannon yksiköissä (THL 2021b). Yksityisillä palvelun- tuottajilla on merkittävä osuus sosiaalihuollon palveluasumisen tarjonnasta, sillä ikääntyneiden tehostetussa palveluasumisessa niiden osuus oli 54 prosenttia (THL 2021b). Pääasiallisin syy iäkkäiden henkilöiden säännöllisten palvelujen käytölle on muistisairaus, joka on noin 200000 suomalaisella. Vähintään keskivaikea muistisairaus on noin 100000 henkilöllä. Säännöllisten palvelujen piirissä olevilla iäkkäillä henkilöillä on suurimmalla osalla muistihäiriö tai muistisairaus muiden somaattisten sairauksien lisäksi. Ympärivuorokautisessa hoidossa noin 80 prosentilla on jokin muistioire. (STM 2020.)

Tehostetun palveluasumisen hoitohenkilöstön osaamisen on todettu olevan hyvää välittömässä perushoidossa, mutta kehittämistarpeita on osaamisessa, joka liittyy asukkaiden hyvinvoinnin kokonaisvaltaiseen tukemiseen (Kiljunen 2019). Osaamisessa on kehitettävää myös palvelutarpeen ja toimintakyvyn arvioinnin sekä tiedon hyödyntämisen asiakassuunnitelmissa sekä hoidon toteutuksessa ja seurannassa (STM 2020). Lisäksi tarvitaan koulutusta henkilöstölle asiakaslähtöisestä ja iäkkäiden toimintakykyä ylläpitävästä ja kuntouttavasta toiminnasta. Henkilöstön osaamista voidaan lisätä monin eri tavoin. Laatusuosituksessa kannustetaan osaamisen vahvistamiseksi henkilökunnan osallistumista vertaiskehittämiseen ja perinteisen täydennyskoulutuksen lisäksi muun muassa erilaisiin kehittämis- ja tutkimushankkeisiin, työkiertoon sekä verkkokoulutuksiin. Tärkeää on myös osaamisen tason seuranta ja arviointi. (STM 2020.) Hoitohenkilöstön osaamisella on yhteys hoidon laatuun ja vaikuttavuuteen (STM 2017). 
Tehostettuun palveluasumiseen siirrytään yleensä vasta, kun kotona selviytyminen on ylivoimaista kognitiivisen tilan ja toimintakyvyn heikkenemisen takia. Tällöin tavoitteena on tarjota hyvää hoitoa siten, että muistisairas henkilö voi elää sairaudestaan huolimatta mahdollisimman täysipainoista ja sosiaalisesti aktiivista elämää omien voimavarojensa puitteissa (Castro-Monteiro ym. 2016) sekä tulla kuulluksi ja saada päättää omista asioistaan (Muistiliitto 2016). Siten muistisairaan toimintakyvyn arviointi ja seuranta sekä päivittäistoiminnoista suoriutumisen tukeminen hänen asuinympäristössään ovat keskeinen osa muistisairaan hoitoa (Hotus 2019). Hyvä ja laadukas hoito perustuu osaamiseen, tutkimukselliseen näyttöön ja kerättyyn tietoon muistisairaan ihmisen ja hänen läheistensä hyvän elämän edellytyksistä sairauden eri vaiheissa. Tietoa tulee koota hoidon toteutusta, seurantaa ja arviointia varten erilaisten mittareiden avulla sekä muistisairaalta ihmiseltä ja hänen läheisiltään. (Muistiliitto 2016.)

Muistisairaan henkilön toimintakyvyn ylläpitämiseksi arjessa tulee olla tarjolla monipuolisesti erilaisia aktiviteetteja ja niiden yhdistelmiä. Paras hyöty saavutetaan pitkäjänteisellä ja säännöllisellä toiminnalla. (Hotus 2019.) Psyykkinen, sosiaalinen ja fyysinen toimintakyky ja aktiivisuus liittyvät saumattomasti yhteen ja vaikuttavat toisiinsa. Sosiaalisella toimintakyvyllä tarkoitetaan kykyä olla, elää ja toimia muiden ihmisten kanssa. Vaikka muistisairaus aiheuttaa ajan kuluessa muutoksia sosiaalisessa toimintakyvyssä ja käyttäytymisessä, muistisairas henkilö kaipaa ja tarvitsee muiden ihmisten seuraa. Sosiaalisista kontakteista eristäytyminen tai eristäminen on vahingollista muistisairaalle ihmiselle. (Mönkäre 2019.) Eräänä aktiviteettien muotona muistisairaan kanssa kannattaa hyödyntää erilaisia kognitiivisia menetelmiä, kuten kognitiivisia harjoitteita ja stimulaatiota. Näitä voidaan toteuttaa sekä yksilökohtaisesti että ryhmämuotoisena toimintana. Muistisairaalle henkilölle on hyvä järjestää mahdollisuuksia myös liikunta-aktiviteetteihin ryhmässä, sillä hän saattaa kokea ryhmän tuen positiivisena ja motivoivana. (Hotus 2019.)

Shiells ja kumppanit (2020) ovat kuvanneet katsausartikkelissaan hoitokotien asukkaiden omia tarpeita ja kokemuksia erilaisista interventioista. Erityisen merkittäväksi osoittautui mielekkään elämän jatkaminen. Minäkuvan säilyttäminen, muistelu ja mahdollisuus osallistua tukivat elämän mielekkyyden kokemusta. Toistaiseksi vahvin näyttö on saatu muistelun ja mielihyvää tuottavien aktiviteettinen käytöstä depressiivisten oireiden vähentämisessä (Testad ym. 2014). Sosiaalisella aktiivisuudella, kuten ryhmätoiminnalla, voi olla myönteisiä tuloksia vahvistava vaikutus (Testad ym. 2014). Cohen-Mansfied ja kumppanit (2015) havaitsivat hoitokodeissa asuvien vaikeasti dementoituneiden henkilöiden yksinäisyyden, virikkeiden vähäisyyden ja mielekkään tekemisen puutteen olevan yleistä. Musiikin soittaminen taustalla on hoitokodeissa yleistä, mutta musiikin mahdollisia hoidollisia ulottuvuuksia ei hyödynnetä riittävästi. Musiikin on todettu olevan lupaava hoidollinen keino vaikuttaa käytösoireisiin ja mielialaan (Dyer ym. 2018; Legere ym. 2018). Musiikin säännöllistä ja suunniteltua hyödyntämistä on hoidollisena elementtinä hoitokodeissa tutkittu toistaiseksi vähän. Suomalainen hoitotyön kehittäminen ikääntyneiden tehostetussa palveluasumisessa on vielä alkuvaiheessa. Hoitohenkilöstön vähäisyyteen ja tehtävänkuviin liittyvät haasteet ovat haitanneet kehittämistyötä.

Tutkimusnäyttöön perustuvan Hoitotyön tutkimussäätiön kokoaman asiantuntijaryhmän laatiman hoitosuosituksen, Muistisairaan henkilön päivittäistoiminnoista suoriutumisen tukeminen - Lääkkeettömät menetelmät hoitotyössä (Hotus 2019), mukaan hoitotyöntekijöiden koulutuksella ja osaamisella sekä osaamisen päivittämisellä ja täydentämisellä on merkitystä muistisairaan henkilön laadukkaan ja potilasturvallisen hoitotyön toteutumisessa. Työnantajan vastuulla on luoda edellytykset sille, että hoitotyöntekijä voi osallistua tarvittavaan ammatilliseen täydennyskoulutukseen, ja työn- 
antajan tulee myös seurata hoitotyöntekijöiden osaamisen tasoa. (Hotus 2019.)

\section{AATOS-hankkeen aloitus koronapandemian myrskynsilmässä}

Koronavirus on tuonut paljon muutoksia meidän kaikkien elämään, mutta kaikkein eniten on muuttunut ikäihmisten arki. Iäkkäillä henkilöillä elimistön puolustuskyky on heikentynyt, ja heillä on myös enemmän pitkäaikaissairauksia, jotka altistavat vakavalle koronavirustaudille. Euroopan tautienehkäisy- ja -valvontakeskuksen laajan aineiston perusteella korkea ikä on merkittävä riskitekijä vakavalle koronavirustaudille, ja myös THL:n seurantatilastojen mukaan suurin osa koronavirustautiin menehtyneistä on ollut yli 70-vuotiaita. Tämän tiedon valossa koronapandemian aikana on pyritty tehostetusti suojaamaan iäkästä väestöä tartunnalta. Tämä on edellyttänyt rajoituksia ja suosituksia ikääntyneiden arjessa, ja nämä ovat vaikuttaneet vahvasti sosiaalisten kontaktien määrään. Haastavassa tilanteessa on tiedostettu yli 70-vuotiaiden henkilöiden perus- ja ihmisoikeuksien kunnioittamisen, toimintakyvyn turvaamisen sekä sosiaalisten ja taloudellisten tarpeiden asettamat vaatimukset. (Kestilä ym. 2020; THL 2020.)

Muun muassa THL:n (2021a) sivuilla jaetaan tietoa siitä, kuinka ikääntyneiden asukkaiden toimintakykyä ja hyvinvointia voidaan muuttuneissa olosuhteissa tukea. Tärkeintä on torjua koronavirustartuntoja pitkäaikaishoidon ja -hoivan yksiköissä. Samaan aikaan tulisi kuitenkin pyrkiä turvaamaan iäkkäiden henkilöiden toimintakyvyn ylläpito. Tähän vastataan omalta osaltaan AATOS-hankkeen toiminnoilla. Hankkeen aloitusvaihe keväällä 2020 osui yhteen koronapandemian alkuvaiheen kanssa, joten hankkeen käynnistämistä jouduttiin lykkäämään syksyyn 2020. Syksyn aikana on toteutettu säännölliset toiminnalliset interventiot huomioiden koronaviruksen aiheuttamat rajoitukset. Erityisen hienoa oli, että yksityisellä palveluntuottajalla oli haastavassa epidemiatilanteessa vahva tahtotila kehittää ikääntyneiden asukkaiden hoitotyötä, ja tutkimusyhteistyö voitiin näin aloittaa.

AATOS-hankkeessa tehdään uudenlaista monialaista ja -tieteistä yhteistyötä. Hanketoimijoita ovat ikääntyneiden palvelujärjestelmän yksityinen asumis- ja hoivapalveluntuottaja, sosiaali- ja terveysalan täydennyskoulutusta tuottava Skhole Oy, laitevalmistaja ja sovelluskehittäjä Sentina $\mathrm{Oy}$, asiantuntijapalveluita tarjoava GeroFuture Oy, Hoitotyön tutkimussäätiö sekä monitieteinen tutkijaverkosto, jota koordinoi Itä-Suomen yliopisto. Tutkijat edustavat Itä-Suomen yliopiston lisäksi Oulun ammattikorkeakoulua ja Oulun yliopistoa.

Hankkeen keskiössä on hoitotyön kehittäminen matalan kynnyksen toimintainterventiolla, joka täydentää palvelukodin tavanomaista toimintaa. Palvelukotien hoitajat ovat suorittaneet Skholen tuottaman verkkokoulutuksen ja saaneet Sentina Oy:n ohjauksen aktivoivien ryhmätoimintojen pitämiseen kyseisen yrityksen tarjoaman digitaalisen Sävelsirkku-palvelun avulla. Verkkokoulutus perustuu tieteelliseen tutkimusnäyttöön lääkkeettömien hoitomenetelmien käytöstä muistisairaiden hoidossa (Tuomikoski ym. 2018). Verkkokoulutus on tehty yhteistyössä Hoitotyön tutkimussäätiön kanssa, ja se pohjautuu kahteen Muistiliiton tilaamaan ja Hoitotyön tutkimussäätiön tuottamaan kirjallisuuskatsaukseen (Tuomikoski ym. 2018; Tuomikoski ym. 2019).

Ryhmätoimintaintervention sisältö toteutuu kahdessa kuuden viikon jaksossa yhteensä 12 viikon ajan. Äänipalvelu Sävelsirkkuun on luotu ryhmätoimintainterventiota varten päivittäiset ohjelmat, jotka sisältävät tutkimushankkeen tavoitteiden mukaiset osiot. Sävelsirkku-ryhmätoimintainterventioiden kesto on 30-45 minuuttia viisi kertaa viikossa. Kukin interventiokerta sisältää päivärytmiä ja orientaatiota tukevan osuuden sekä toiminnallisen osuuden, minäkuvaa tukevia muisteluita, oh- 
jattuja keskusteluja ja liikunnallisen osuuden. Jokainen ryhmätoimintainterventiokerta päättyy rauhoittavaan musiikkiin.

Hoitajien osaaminen liittyen muistisairaiden lääkkeettömään hoitoon sekä arviot lääkkeettömän hoidon ja ryhmätoiminnan merkityksestä hoitotyössä kartoitetaan tätä tutkimushanketta varten laaditulla sähköisellä kyselyllä ennen koulutusta ja intervention jälkeen. Ikääntyneiden hoivakotien asukkaiden toimintakykyä, masennusoireita ja sosiaalista osallistumishalukkuutta arvioidaan hyödyntäen RAI-mittauksia, joita tehdään osana hoivakotien tavanomaista hoitoa ennen ryhmäintervention alkamista ja sen päätyttyä. Ryhmätoimintaintervention päätyttyä aineisto analysoidaan ja raportoidaan sekä kansallisina että kansainvälisinä tieteellisinä artikkeleina. Tulokset esitetään myös kohdeorganisaation henkilökunnalle, ja niitä hyödynnetään päivittäisten ryhmätoimintojen kehittämisessä.

\section{AATOS-hankkeen yhteiskunnallinen ja tieteellinen merkitys}

Tutkimushankkeen vahvuutena on hoitajavastuinen ryhmätoiminta, joka tukee hoivakotien päivittäistä toimintaa lisäämättä kustannuksia. Tavoitteena on, että hanke parantaa paitsi ikääntyneiden toimintakykyä ja sosiaalista osallistumista myös hoidon laatua ja hoitohenkilöstön osaamista sekä lisää työn mielekkyyttä. Hankkeen tulokset antavat tietoa aktivoivan ryhmätoiminnan vaikutuksista ja toimintamallin hyödynnettävyydestä iäkkäiden pitkäaikaishoidossa. Tavoitteena on muuttaa ikääntyneiden muistisairaiden hoitokulttuuria, edistää mielekästä arkea hoivakodissa ja tukea muistisairaiden toimintakyvyn ylläpysymistä tehostetussa palveluasumisessa. Yhteiskunnallisesti hankkeen tavoitteena on edistää iäkkäiden hoitotyön näyttöön perustuvaa toimintaa, lisätä ikääntyneiden hoitotyön houkuttelevuutta sekä tukea hoitohenkilökunnan työssä jaksamista ja työhyvinvointia. Tieteellisesti tutki- mushanke tuottaa tärkeää uutta hoitotieteellistä tietoa muistisairaiden lääkkeettömän hoidon vaikuttavuudesta ja hoitohenkilökunnan osaamisesta.

\section{AATOS-tutkimusryhmä:}

Heidi Siira, Oulun yliopisto, heidi.siira@oulu.fi

Reetta Saarnio, Oulun ammattikorkeakoulu ja Oulun yliopisto

Outi Kiljunen, Itä-Suomen yliopisto

Anna-Maria Tuomikoski, Oulun ammattikorkeakoulu ja Oulun yliopisto

Katriina Niemelä, GeroFuture Oy

Pia Vähäkangas, GeroFuture $\mathrm{Oy}$

Tarja Välimäki, hankkeen vastuullinen johtaja, Itä-Suomen yliopisto, tarja.valimaki@uef.fi

\section{Kirjallisuus}

Castro-Monteiro E, Alhayek-Aí M, Diaz-Redondo A, Ayala A, Rodriguez-Blazquez C, Rojo-Perez F, et al. Quality of life of institutionalized older adults by dementia severity. Int Psychogeriatr 2016;28(1):83-92. https://doi.org/10.1017/s1041610215000757

Cohen-Mansfield J, Dakheel-Ali M, Marx MS, Thein $\mathrm{K}$, Regier NG. Which unmet needs contribute to behavior problems in persons with advanced dementia? Psychiatry Res 2015;228(1):59-64. https://doi.org/10.1016/j.psychres.2015.03.043

Dyer SM, Harrison SL, Laver K, Whitehead C, Crotty M. An overview of systematic reviews of pharmacological and non-pharmacological interventions for the treatment of behavioral and psychological symptoms of dementia. Int Psychogeriatr 2018;30(3):295-309.

https://doi.org/10.1017/s1041610217002344

Hotus. Muistisairaan henkilön päivittäistoiminnoista suoriutumisen tukeminen - Lääkkeettömät menetelmät hoitotyössä. Hoitotyön tutkimussäätiö, 2019. Internet: https://www.hotus.fi/wp-content/uploads/2019/12/hoitosuositus-muistisairaat.pdf (viitattu 21.11.2021). 
Kestilä L, Härmä V, Rissanen P, toim. Covid-19-epidemian vaikutukset hyvinvointiin, palvelujärjestelmään ja kansantalouteen: asiantuntija-arvio, syksy 2020. THL Raportti 14, 2020.

Kiljunen O. Care home nursing professionals' competence in older people nursing. Publications of the University of Eastern Finland. Dissertations in Health Sciences, 492. Kuopio, 2019.

Legere L, McNeill S, Schindel Martin L, Acorn M, An D. Nonpharmacological approaches for behavioural and psychological symptoms of dementia in older adults: a systematic review of reviews. J Clin Nurs 2018;27(7-8):e1360-76. https://doi.org/10.1111/jocn.14007

Muistiliitto 2016. Hyvän hoidon kriteeristö: työkirja työyhteisöille muistisairaiden ihmisten hyvän hoidon ja elämänlaadun kehittämiseen ja arviointiin. Muistiliiton julkaisusarja 2/2016. Internet: https://muistiliitto.vuolearning.fi/courses/ hyvaen-hoidon-kriteeristoe/tervetuloa (viitattu 21.11.2021).

Mönkäre R. 2019. Muistisairaan psyykkisen ja sosiaalisen toimintakyvyn tukeminen. Teoksessa: Hallikainen M, Immonen A, Mönkäre R, Pihlakari P, toim. Muistisairaan hoito. Helsinki: Duodecim, 2019:131-4.

Shiells K. Pivodic L, Holmerová I, Van den Block L. Self-reported needs and experiences of people with dementia living in nursing homes: a scoping review. Aging Ment Health 2020;24(10):155368.

https://doi.org/10.1080/13607863.2019.1625303

STM. Laatusuositus hyvän ikääntymisen turvaamiseksi ja palvelujen parantamiseksi 2017-2019. Sosiaali- ja terveysministeriön julkaisuja 2017:6. Helsinki.

STM. Laatusuositus hyvän ikääntymisen turvaamiseksi ja palvelujen parantamiseksi 2020-2023: tavoitteena ikäystävällinen Suomi. Sosiaali- ja terveysministeriön julkaisuja 2020:29. Helsinki. http://urn.fi/URN:ISBN:978-952-00-5457-1

Testad I, Corbett A, Aarsland D, Lexow KO, Fossey J, Woods B, Ballard C. The value of personalized psychosocial interventions to address behavioral and psychological symptoms in people with dementia living in care home settings: a systematic review. Int Psychogeriatr 2014;26(7):1083-98. https://doi.org/10.1017/s1041610214000131

THL. Ikääntyneet ja muut riskiryhmät -ohjeita koronavirusepidemian aikana. Terveyden ja hyvinvoinnin laitos, 2020. Internet: https://thl.fi/fi/ web/infektiotaudit-ja-rokotukset/ajankohtaista/ ajankohtaista-koronaviruksesta-covid-19/vakavan-koronavirustaudin-riskiryhmat/ikaantyneetja-muut-riskiryhmat-ohjeita-koronavirusepidemian-aikana (viitattu 21.11.2021).

THL. Vinkkejä ympärivuorokautiseen hoitoon koronavirusepidemian aikana. Terveyden ja hyvinvoinnin laitos, 2021a. Internet: https://thl.fi/fi/ web/ikaantyminen/ajankohtaista/vinkkeja-ymparivuorokautiseen-hoitoon-koronavirusepidemian-aikana (viitattu 21.11.2021).

THL. Sosiaalihuollon laitos- ja asumispalvelut 2020. Tilastoraportti 39/2021. Terveyden ja hyvinvoinnin laitos, 2021b. Internet: https://www.julkari.fi/ bitstream/handle/10024/143302/Tr39_21.pdf?sequence=1\&isAllowed=y (viitattu 21.11.2021).

Tuomikoski A, Parisod H, Oikarainen A, Siltanen H, Holopainen A. Lääkkeettömien menetelmien vaikutukset muistisairaan haasteelliseksi koettuun käyttäytymiseen - Raportti järjestelmällisten katsausten katsauksista. Muistiliiton julkaisusarja 1/2018. Internet: https://www.muistiliitto.fi/application/files/9315/4227/2682/Katsaus_ laakkeettomat.pdf (viitattu 21.11.2021).

Tuomikoski A, Parisod H, Oikarainen A, Siltanen H, Holopainen A. Lääkkeettömien menetelmien vaikutukset muistisairaan päivittäisistä toiminnoista selviytymiseen - Raportti järjestelmällisten katsausten katsauksista. Muistiliiton julkaisusarja 1/2019. Internet: https://www.muistiliitto. fi/application/files/8915/5134/0010/Laakkeettomien_menetelmien_vaikutukset_muistisairautta_sairastavan_paivittaisista_toiminnoista_ selviytymiseen.pdf (viitattu 21.11.2021). 